\title{
EKSTRAK BIJI ASAM JAWA (Tamarindus Indica) SEBAGAI KOAGULAN LIMBAH CAIR INDUSTRI TEMPE TAHUN 2017
}

Fulan Oktaviana Hardi, S.B. Eko W, Pratiwi Hermiyanti

\begin{abstract}
ABSTRAK
Limbah cair tempe mengandung zat organik yang terdiri dari protein, karbohidrat, dan lemak yang apabila tidak dilakukan pengolahan dengan baik dapat meningkatkan pencemaran udara berupa bau yang tidak sedap dan pencemaran air yang berupa peningkatan nilai BOD, COD, TSS, dan pH. Asam jawa memiliki kandungan tannin yang dapat berperan sebagai koagulan karena dapat larut dalam air. Tujuan penelitian ini adalah mencari dosis koagulan ekstrak biji asam jawa paling rendah yang dapat menurunkan paling tinggi pengendapan zat pencemar sehingga dapat memenuhi baku mutu lingkungan.

Penelitian ini menggunakan desain Penelitian "Pretest-Postest with Control Group" dengan variasi dosis ekstrak biji asam jawa $(600 \mathrm{mg} / \mathrm{L}, 900 \mathrm{mg} / \mathrm{L}, 1200 \mathrm{mg} / \mathrm{L}$, dan $1500 \mathrm{mg} / \mathrm{L})$, dengan menggunakan metode jar test untuk diperoleh hasil yang optimum yang akan digunakan pada pengujian parameter BOD, COD, TSS, dan pH limbah cair industri tempe. Penelitian ini menggunakan Uji statistic yaitu One Way Anova.

Berdasarkan hasil penelitian yang telah dilakukan diketahui Sebelum dilakukan pengolahan kadar BOD sebesar 432,69 mg/L, COD sebesar 712,75 mg/L, TSS sebesar $708 \mathrm{mg} / \mathrm{L}$, dan $\mathrm{pH}$ sebesar 4 sehingga parameter tersebut belum memenuhi baku mutu limbah cair yang telah ditetapkan kemudian dilakukan pengolahan dengan penambahan ekstrak biji asam jawa dan didapatkan BOD sebesar $75 \mathrm{mg} / \mathrm{L}$, COD sebesar 173,52 mg/L, TSS sebesar $100 \mathrm{mg} / \mathrm{L}$, dan $\mathrm{pH}$ sebesar 7 sehingga parameter tersebut telah memenuhi baku mutu limbah cair yang telah ditetapkan.

Dapat disimpulkan bahwa Dosis efektif untuk koagulan biji asam jawa (Tamarindus indica) adalah dosis $1500 \mathrm{mg}$ sehingga parameter BOD, COD, TSS, dan pH telah memenuhi baku mutu limbah cair yang telah ditetapkan. Saran yang dapat diberikan bahwa perlu dilakukan pengujian dengan penambahan variasi dosis asam jawa dibawah $1500 \mathrm{mg} / \mathrm{L}$ tetapi berifat efektif dan penggunaan koagulan jenis lainnya untuk penurunan parameter pencemaran limbah cair.
\end{abstract}

Kata Kunci : Limbah Cair tempe, Biji Asam jawa, Parameter BOD, COD, TSS, dan pH

\section{PENDAHULUAN}

Permasalahan

lingkungan terutama masalah pencemaran air di kota-kota besar di Indonesia saat ini semakin serius. Pencemaran air disebabkan oleh limbah seperti limbah industri. Salah satu industri yang yang menimbulkan pencemaran air adalah industri tempe. Limbah cair yang dihasilkan pada proses pembuatan tempe umumnya mengandung $99,9 \%$ air dan $0,1 \%$ padatan. Limbah cair terdiri dari $70 \%$ padatan organik dan $30 \%$ padatan anorganik. Padatan Organik dari limbah cair berupa protein $65 \%$, karbohidrat $25 \%$ dan lemak 10\% (Nurhasan dan Pramudyanto, 1987), sedangkan padatan anorganik berupa butiran garam dan logam. Apabila zat organic tidak olah maka menimbulkan gas Hydrogen Sulfide $\left(\mathrm{H}_{2} \mathrm{~S}\right)$, ammonia $\left(\mathrm{NH}_{3}\right)$, dan metana $\left(\mathrm{CH}_{4}\right)$ yang dapat menyebabkan timbulnya bau sehingga hasil penguraian zat organik oleh mikroba secara anaerob (Sugiharto, 1987). Dampak buruk kesehatan yaitu timbulnya penyakit seperti gatal-gatal dan gangguan pada pernafasan karena menghirup udara yang tercemar bau busuk.

Salah satu alternatif pengolahan limbah cair tempe yang mudah, murah dan efektif tersebut adalah dengan metode koagulasi dan flokulasi dengan menggunakan alat jar test dan menggunakan koagulan biji asam jawa (Tamarindus Indica). Pada Umumnya biji asam jawa dapat digunakan sebagai koagulan pada proses koagulasi karena tanin merupakan senyawa phenolic yang dapat larut dalam air. Berat molekul 300500 dapat mengendapkan protein dari 
larutan. Warna kulit tanin semakin gelap, menandakan kandungan semakin tinggi. Kandungan tannin $20,2 \%$ pada kulit dan kandungan pati $33,1 \%$. Pada penelitian ini serbuk biji asam jawa digunakan sebagai koagulan alternatif dengan bahan alami pada pengolahan limbah cair tempe untuk mengetahui pengaruh biji asam jawa terhadap parameter kualitas limbah cair tempe yaitu BOD, COD, TSS, dan pH.

\section{METODE PENELITIAN}

Penelitian ini merupakan penelitian eksperimen murni (true experimental) dengan rancangan "Pretest-Postest with Control Group". Obyek penelitian ini adalah limbah cair hasil perebusan dalam proses pembuatan tempe dari Home Industri di Kelurahan Sidosermo, Kecamatan Wonocolo, Kota Surabaya. Sampel yang digunakan adalah 25 liter limbah cair dengan dengan pembagian 5 liter untuk kelompok kontrol dan 20 liter untuk kelompok eksperimen. Ekstrak biji asam jawa yang digunakan dengan variasi $600 \mathrm{mg} / \mathrm{L}, 900 \mathrm{mg} / \mathrm{L}, 1200 \mathrm{mg} / \mathrm{L}$, dan $1500 \mathrm{mg} / \mathrm{L}$ dengan kecepatan pengadukan 1 menit dan waktu pengadukan 5 menit dan waktu pengendapan selama 60 menit.

\section{HASIL DAN PEMBAHASAN \\ Parameter limbah cair tempe sebelum penambahan koagulan ekstrak biji asam jawa \\ Pengukuran awal sebelum} diberikan penambahan ekstrak biji asam jawa (Tamarindus indica) didapatkan nilai BOD sebesar $432,69 \mathrm{mg} / \mathrm{L}$. Nilai COD sebesar $712,75 \mathrm{mg} / \mathrm{L}$, nilai TSS sebesar $708 \mathrm{mg} / \mathrm{L}$, dan nilai $\mathrm{pH}$ sebesar 4, sehingga nilai parameter tersebut melebihi kadar maksimum parameter yang telah ditetapkan dalam Peraturan Gubernur Jawa Timur nomor 72 tahun 2013 tentang baku mutu air limbah bagi industri dan atau kegiatan usaha lainnya bagi industri pengolahan kedelai.

\section{Parameter limbah cair tempe sesudah penambahan dosis koagulan ekstrak biji asam jawa Parameter BOD}

Tabel 1

PENGARUH VARIASI DOSIS EKSTRAK BIJI ASAM JAWA (Tamarindus indica) TERHADAP PENURUNAN PARAMETER BOD LIMBAH CAIR TEMPE

\begin{tabular}{ccccc}
\hline \multirow{2}{*}{ No } & Dosis & Sebelum & Setelah & $\begin{array}{c}\text { Efektivitas } \\
\text { Penurunan } \\
(\%)\end{array}$ \\
\cline { 3 - 4 } & & & & \multicolumn{2}{c}{ Parameter BOD } \\
\hline 1 & $600 \mathrm{mg} / \mathrm{L}$ & 432,69 & 271,78 & $37,2 \%$ \\
\hline 2 & $900 \mathrm{mg} / \mathrm{L}$ & 432,69 & 170,37 & $60,6 \%$ \\
\hline 3 & $1200 \mathrm{mg} / \mathrm{L}$ & 432,69 & 92,47 & $78,6 \%$ \\
\hline 4 & $1500 \mathrm{mg} / \mathrm{L}$ & 432,69 & 75,32 & $82,6 \%$ \\
\hline
\end{tabular}

Berdasarkan penelitian yang telah dilakukan nilai parameter BOD pada limbah cair tempe sebelum dilakukan pengolahan sebesar $432,69 \mathrm{mg} / \mathrm{L}$ sedangkan setelah dilakukan pengolahan dengan penambahan ekstrak biji asam jawa (Tamarindus indica) pada dosis 600 $\mathrm{mg} / \mathrm{L}$ hanya dapat menurunkan nilai parameter BOD sebesar 271,78 mg/L namun hasil tersebut tidak dapat memenuhi baku mutu limbah cair tempe. Pada dosis $900 \mathrm{mg} / \mathrm{L}$ dapat menurunkan nilai parameter BOD sebesar $170,37 \mathrm{mg} / \mathrm{L}$ namun hasil tersebut belum dapat memenuhi baku mutu limbah cair tempe. Pada dosis $1200 \mathrm{mg} / \mathrm{L}$ dapat menurunkan nilai parameter BOD sebesar $92,32 \mathrm{mg} / \mathrm{L}$ sehingga hasil tersebut dapat memenuhi baku mutu limbah cair tempe. Pada dosis $1500 \mathrm{mg} / \mathrm{L}$ dapat menurunkan nilai parameter BOD sebesar 75,32 $\mathrm{mg} / \mathrm{L}$ sehingga hasil tersebut mampu memenuhi baku mutu limbah cair tempe.

Koagulan yang digunakan adalah Ekstrak biji asam jawa (Tamarindus indica) karena mengandung zat aktif berupa tanin mempunyai kemampuan mengikat bahan-bahan organik dalam limbah cair tempe yang komponen terbesarnya adalah protein menjadi cepat mengikat dan mengendap sehingga mengalami penurunan dan nilai 
parameter BOD memenuhi baku mutu limbah cair yang telah ditentukan.

Setelah dilakukan penelitian nilai BOD yang telah dilakukan oleh peneliti telah memenuhi baku mutu yang telah ditetapkan Peraturan Gubernur Jawa Timur nomor 72 tahun 2013 tentang baku mutu limbah cair bagi industri atau kegiatan usaha lainnya untuk industri pengolahan kedelai sebagai tempe dengan nilai $B O D$ sebesar $75,32 \mathrm{mg} / \mathrm{L}$ telah memenuhi baku mutu limbah cair industri tempe dimana nilai kadar maksimum BOD sebesar $150 \mathrm{mg} / \mathrm{L}$.

\section{Parameter COD}

Tabel 2

PENGARUH VARIASI DOSIS EKSTRAK BIJI ASAM JAWA (Tamarindus indica) TERHADAP PENURUNAN PARAMETER COD LIMBAH CAIR TEMPE

\begin{tabular}{|c|c|c|c|c|}
\hline \multirow[b]{2}{*}{ NO } & \multirow[b]{2}{*}{ Dosis } & \multicolumn{2}{|c|}{ Parameter COD } & \multirow{2}{*}{$\begin{array}{c}\text { Efektivitas } \\
\text { Penurunar } \\
(\%)\end{array}$} \\
\hline & & Sebelum & Setelah & \\
\hline 1 & $600 \mathrm{mg} / \mathrm{L}$ & 712,75 & 410,71 & $43,4 \%$ \\
\hline 2 & $900 \mathrm{mg} / \mathrm{L}$ & 712,75 & 325,67 & $54,3 \%$ \\
\hline 3 & $1200 \mathrm{mg} / \mathrm{L}$ & 712,75 & 185,48 & $74 \%$ \\
\hline 4 & $1500 \mathrm{mg} / \mathrm{L}$ & 712,75 & 153,52 & $78,5 \%$ \\
\hline
\end{tabular}

Berdasarkan penelitian yang telah dilakukan nilai parameter COD pada limbah cair tempe sebelum dilakukan pengolahan sebesar $712,75 \mathrm{mg} / \mathrm{L}$ sedangkan setelah dilakukan pengolahan dengan penambahan ekstrak biji asam jawa (Tamarindus indica) pada dosis 600 $\mathrm{mg} / \mathrm{L}$ hanya dapat menurunkan nilai parameter COD sebesar 410,71 $\mathrm{mg} / \mathrm{L}$ namun hasil tersebut tidak dapat memenuhi baku mutu limbah cair tempe. Pada dosis $900 \mathrm{mg} / \mathrm{L}$ dapat menurunkan nilai parameter COD sebesar $325,67 \mathrm{mg} / \mathrm{L}$ namun hasil tersebut belum dapat memenuhi baku mutu limbah cair tempe. Pada dosis $1200 \mathrm{mg} / \mathrm{L}$ dapat menurunkan nilai parameter COD sebesar $185,48 \mathrm{mg} / \mathrm{L}$ sehingga hasil tersebut dapat memenuhi baku mutu limbah cair tempe. Pada dosis $1500 \mathrm{mg} / \mathrm{L}$ dapat menurunkan nilai parameter COD sebesar $153,52 \mathrm{mg} / \mathrm{L}$ sehingga hasil tersebut mampu memenuhi baku mutu limbah cair tempe.
Koagulan yang digunakan adalah Ekstrak biji asam jawa (Tamarindus indica) karena mengandung zat aktif berupa tannin yang mempunyai kemampuan mengikat bahan-bahan organik dalam limbah cair tempe yang komponen terbesarnya adalah protein menjadi cepat mengikat dan mengendap sehingga mengalami penurunan dan nilai parameter COD memenuhi baku mutu limbah cair yang telah ditentukan.

Setelah dilakukan penelitian nilai COD yang telah dilakukan oleh peneliti telah memenuhi baku mutu yang telah ditetapkan Peraturan Gubernur Jawa Timur nomor 72 tahun 2013 tentang baku mutu limbah cair bagi industri atau kegiatan usaha lainnya untuk industri pengolahan kedelai sebagai tempe dengan nilai COD sebesar 153,52 mg/L telah memenuhi baku mutu limbah cair industri tempe dimana nilai kadar maksimum COD sebesar $300 \mathrm{mg} / \mathrm{L}$.

\section{Parameter TSS}

Tabel 3

PENGARUH VARIASI DOSIS EKSTRAK BIJI ASAM JAWA (Tamarindus indica) TERHADAP PENURUNAN PARAMETER TSS LIMBAH CAIR TEMPE

\begin{tabular}{ccccc}
\hline \multirow{2}{*}{ NO } & \multirow{2}{*}{ Dosis } & \multicolumn{2}{c}{ Parameter TSS } & $\begin{array}{c}\text { Efektivitas } \\
\text { Penurunan (\%) }\end{array}$ \\
\hline 1 & $600 \mathrm{mg} / \mathrm{L}$ & 708 & 430 & $39,7 \%$ \\
\hline 2 & $900 \mathrm{mg} / \mathrm{L}$ & 708 & 326 & $53,9 \%$ \\
\hline 3 & $1200 \mathrm{mg} / \mathrm{L}$ & 708 & 127 & $82,1 \%$ \\
\hline 4 & $1500 \mathrm{mg} / \mathrm{L}$ & 708 & 96 & $86,4 \%$ \\
\hline
\end{tabular}


Berdasarkan penelitian yang telah dilakukan nilai parameter TSS pada limbah cair tempe sebelum dilakukan pengolahan sebesar $708 \mathrm{mg} / \mathrm{L}$ sedangkan setelah dilakukan pengolahan dengan penambahan ekstrak biji asam jawa (Tamarindus indica) pada dosis $600 \mathrm{mg} / \mathrm{L}$ hanya dapat menurunkan nilai parameter TSS sebesar $430 \mathrm{mg} / \mathrm{L}$ namun hasil tersebut tidak dapat memenuhi baku mutu limbah cair tempe. Pada dosis 900 $\mathrm{mg} / \mathrm{L}$ dapat menurunkan nilai parameter TSS sebesar $326 \mathrm{mg} / \mathrm{L}$ namun hasil tersebut tidak dapat memenuhi baku mutu limbah cair tempe. Pada dosis 1200 $\mathrm{mg} / \mathrm{L}$ dapat menurunkan nilai parameter TSS sebesar $127 \mathrm{mg} / \mathrm{L}$ sehingga hasil tersebut belum dapat memenuhi baku mutu limbah cair tempe. Pada dosis 1500 $\mathrm{mg} / \mathrm{L}$ dapat menurunkan nilai parameter TSS sebesar $96 \mathrm{mg} / \mathrm{L}$ sehingga hasil tersebut mampu memenuhi baku mutu limbah cair tempe.
Serbuk biji asam jawa memiliki senyawa pati yang dapat mempercepat pembentukan flok, dengan cara menghubungkan partikel muatan positif pada kombinasi koagulan dan muatan negatif pada limbah cair tempe. Senyawa pati yang terdapat pada biji asam jawa berfungsi sebagai penghubung antar partikel muatan positif dan negatif melalui proses adsorbs.

Setelah dilakukan penelitian nilai TSS yang telah dilakukan oleh peneliti telah memenuhi baku mutu yang telah ditetapkan Peraturan Gubernur Jawa Timur nomor 72 tahun 2013 tentang baku mutu limbah cair bagi industri atau kegiatan usaha lainnya untuk industri pengolahan kedelai sebagai tempe dengan nilai TSS sebesar $96 \mathrm{mg} / \mathrm{L}$ telah memenuhi baku mutu limbah cair industri tempe dimana nilai kadar maksimum TSS sebesar $100 \mathrm{mg} / \mathrm{L}$.

\section{Parameter pH}

Tabel 4

PENGARUH VARIASI DOSIS EKSTRAK BIJI ASAM JAWA (Tamarindus indica) TERHADAP KENAIKAN PARAMETER PH LIMBAH CAIR TEMPE

\begin{tabular}{|c|c|c|c|c|}
\hline \multirow{2}{*}{ NO } & \multirow{2}{*}{ Dosis } & \multicolumn{2}{|c|}{ Parameter pH } & \multirow{2}{*}{$\begin{array}{c}\text { Efektivitas } \\
\text { Penurunan }(\%)\end{array}$} \\
\hline & & Sebelum & Setelah & \\
\hline 1 & $600 \mathrm{mg} / \mathrm{L}$ & 4 & 7 & \multirow{4}{*}{$75 \%$} \\
\hline 2 & $900 \mathrm{mg} / \mathrm{L}$ & 4 & 7 & \\
\hline 3 & $1200 \mathrm{mg} / \mathrm{L}$ & 4 & 7 & \\
\hline 4 & $1500 \mathrm{mg} / \mathrm{L}$ & 4 & 7 & \\
\hline
\end{tabular}

Nilai parameter $\mathrm{pH}$ sebelum diberi perlakuan mempunyai nilai yang asam yaitu 4. Menurut Peraturan Gubernur Jatim nomor 72 tahun 2013 batas maksimum konsentrasi $\mathrm{pH}$ didalam limbah cair tempe adalah $6,0-9,0, \mathrm{pH}$ yang bersifat asam dipengaruhi oleh kandungan bahan organik yang terdapat didalam limbah cair tempe yang komponen utamanya adalah protein, volume limbah yang dibuang kebadan air, serta frekuensi pembuangan limbah.

Untuk menaikkan nilai pH limbah cair tempe yang pada awalnya rendah dan tidak memenuhi baku mutu limbah cair maka perlu dilakukan pengolahan dengan penambahan ekstrak biji asam jawa (Tamarindus indica) karena biji asam jawa memiliki nilai kadar $\mathrm{pH}$ sebesar 2-4 sehingga lebih cocok digunakan sebagai koagulan pada pengolahan limbah cair tempe yang memiliki pH asam.

\section{Efektivitas Ekstrak Biji Asam Jawa terhadap Penurunan Parameter limbah cair tempe}

Penambahan ekstrak biji asam jawa terhadap penurunan parameter BOD, COD, TSS, dan $\mathrm{pH}$ pada limbah cair tempe berdasarkan uji One Way Anova diperoleh hasil $p=0,000<0,05$ maka dapat disimpulkan bahwa maka terdapat perbedaan yang signifikan untuk parameter BOD, COD, TSS, dan $\mathrm{pH}$ sebelum dan sesudah dilakukan penambahan ekstrak biji asam jawa (Tamarindus indica). 
Penurunan parameter BOD tertinggi terjadi pada dosis $1500 \mathrm{mg}$ dengan nilai sebesar $75,32 \mathrm{mg} / \mathrm{L}$ dengan persentase penurunan sebesar $82,6 \%$. Sedangkan penurunan parameter BOD terendah terjadi pada dosis $600 \mathrm{mg}$ dengan nilai sebesar $271,78 \mathrm{mg} / \mathrm{L}$ dengan persentase sebesar $37,2 \%$. Penurunan parameter COD tertinggi terjadi pada dosis $1500 \mathrm{mg}$ dengan nilai sebesar $153,52 \mathrm{mg} / \mathrm{L}$ dengan persentase penurunan sebesar 78,5\%. Sedangkan penurunan parameter COD terendah terjadi pada dosis $600 \mathrm{mg}$ dengan nilai sebesar $410,71 \mathrm{mg} / \mathrm{L}$ dengan persentase sebesar $42,4 \%$. Penurunan parameter TSS tertinggi terjadi pada dosis $1500 \mathrm{mg}$ dengan nilai sebesar $96 \mathrm{mg} / \mathrm{L}$ dengan persentase penurunan sebesar $86,4 \%$. Sedangkan penurunan parameter TSS terendah terjadi pada dosis $600 \mathrm{mg}$ dengan nilai sebesar $430 \mathrm{mg} / \mathrm{L}$ dengan persentase sebesar $39,7 \%$. Parameter $\mathrm{pH}$ pada limbah cair tempe sebelum diberikan perlakuan dengan penambahan dosis ekstrak biji asam jawa yaitu 4 kemudian sesudah diberikan perlakuan penambahan ekstrak biji asam jawa mengalami kenaikan nilai yaitu 7 dengan persentase $75 \%$.

Pemerintah menetapkan Peraturan Gubernur Jawa Timur nomor 72 tahun 2013 sebagai peraturan yang berkaitan dengan kadar maksimum parameter BOD, COD, TSS, dan $\mathrm{pH}$ dalam limbah cair tempe. Pada peraturan tersebut kadar maksimum untuk parameter BOD sebesar $150 \mathrm{mg} / \mathrm{L}$, COD sebesar $300 \mathrm{mg} / \mathrm{L}$, TSS sebesar $100 \mathrm{mg} / \mathrm{L}$, dan $\mathrm{pH}$ sebesar 6,0 9,0. sebesar $300 \mathrm{mg} / \mathrm{L}$, TSS sebesar 100 $\mathrm{mg} / \mathrm{L}$, dan $\mathrm{pH}$ sebesar 6,0 -9,0. Pada penelitian ini limbah cair tempe sebelum diberikan perlakuan penambahan ekstrak biji asam jawa memiliki nilai BOD sebesar $432,69 \mathrm{mg} / \mathrm{L}$, COD sebesar $712,75 \mathrm{mg} / \mathrm{L}$, TSS sebesar $708 \mathrm{mg} / \mathrm{L}$, dan pH sebesar 4 . Setelah diberikan perlakuan penambahan ekstrak biji asam jawa (Tamarindus indica) dengan variasi dosis $600 \mathrm{mg}, 900$ $\mathrm{mg}, 1200 \mathrm{mg}$, dan $1500 \mathrm{mg}$ didapatkan hasil bahwa penambahan ekstrak biji asam jawa pada dosis $600 \mathrm{mg}$ dan 900 $\mathrm{mg}$ masih belum dapat menurunkan parameter BOD, COD, TSS, dan pH sesuai dengan baku mutu limbah cair yang sudah di tetapkan yaitu nilai BOD sebesar $75,35 \mathrm{mg} / \mathrm{L}$, COD sebesar 153,52 mg/L, TSS sebesar $96 \mathrm{mg} / \mathrm{L}$, dan $\mathrm{pH}$ sebesar 7 . Pada dosis $1200 \mathrm{mg}$ untuk parameter BOD, COD dan $\mathrm{pH}$ sudah dapat memenuhi baku mutu limbah cair yang sudah ditetapkan sedangan parameter TSS belum dapat memenuhi baku mutu limbah cair yang sudah ditetapkan sedangkan penambahan dosis $1500 \mathrm{mg}$ pada limbah cair dapat menurunkan parameter BOD, COD, TSS, dan pH sesuai dengan baku mutu limbah cair tempe menurut Peraturan Gubernur Jawa Timur nomor 72 tahun 2013.

\section{Kesimpulan}

1. Sebelum dilakukan pengolahan nilai parameter BOD sebesar $432,69 \mathrm{mg} / \mathrm{L}$, COD sebesar $712,75 \mathrm{mg} / \mathrm{L}$, TSS sebesar $708 \mathrm{mg} / \mathrm{L}$, dan $\mathrm{pH}$ sebesar 4 sehingga parameter tersebut belum memenuhi baku mutu limbah cair tempe yang telah ditetapkan.

2. Setelah dilakukan dilakukan pengolahan dengan penambahan ekstrak biji asam jawa (Tamarindus indica) didapatkan hasil nilai parameter BOD dengan persentase $82,6 \%$, COD dengan persentase $78,5 \%$, TSS dengan persentase $86,4 \%$, dan $\mathrm{pH}$ sebesar 7 sehingga parameter tersebut sudah memenuhi baku mutu air limbah cair tempe yang telah ditetapkan.

3. Dosis efektif untuk koagulan biji asam jawa (Tamarindus indica) adalah dosis $1500 \mathrm{mg}$

4. Setelah dilakukan pengolahan didapatkan hasil nilai parameter BOD sebesar $75,32 \mathrm{mg} / \mathrm{L}$, nilai COD sebesar $153,52 \mathrm{mg} / \mathrm{L}$, nilai TSS sebesar $96 \mathrm{mg} / \mathrm{L}$, dan $\mathrm{pH}$ sebesar 7 sehingga nilai yang didapatkan sudah memenuhi baku mutu air limbah untuk industri tempe berdasarkan Peraturan Gubernur Jawa Timur Nomor 72 tahun 2013 tentang baku mutu air limbah Industri dan atau kegiatan lainnya. 


\section{Saran}

1. Bagi Pemilik Industri Tempe

Disarankan kepada pemilik industri tempe bahwa ekstrak biji asam jawa (Tamarindus indica) dapat digunakan sebagai koagulan alami dalam pengolahan limbah cair tempe untuk menurunkan parameter BOD, COD, TSS, dan $\mathrm{pH}$ sebelum dibuang ke badan air.

2. Bagi Peneliti Lain

Diperlukan adanya penelitian lanjutan mengenai :

a. Perlu dilakukan pengujian dengan penambahan variasi dosis asam jawa dibawah $1500 \mathrm{mg} / \mathrm{L}$ tetapi bersifat efektif untuk penurunan parameter pencemaran limbah cair.

b. Perlu dilakukan pengujian dengan penggunaan jenis koagulan lainnya yang dapat menurunkan parameter pencemaran air limbah.

\section{DAFTAR PUSTAKA}

Cahyadi, Wisnu, 2012. Kedelai Khasiat dan teknologi. Jakarta : PT Bumi Aksara. Edisi Ketiga.

Dyah, Eko, Soehartini, 2015. Pemanfaatan Biji Asam Jawa (Tamarindus Indica) Sebagai Koagulan Alami Dalam Pengolahan Limbah Cair Industri Farmasi. Jurnal penelitian. Bandung : Jurusan Kimia, Fakultas Sains dan terapan

Etik, Budi, Wisnu. 2016. Pemanfaatan Serbuk Biji Asam Jawa (Tamarindus Indica L) Untuk Pengolahan Limbah Cair Tempe. Semarang : Jurusan Kimia Universitas Negeri Semarang

Ramadhani, GI, Moesriati, A. 2013. Pemanfaatan Biji Asam Jawa (Tamarindus indica) Sebagai Koagulan Alternatif Dalam Proses Menurunkan Kadar COD Dan BOD Dengan Studi Kasus Pada Limbah Cair Industri Tempe. Surabaya : Jurusan Teknik Lingkungan, Institut Teknologi Sepuluh Nopember (ITS)

Hery, Rochawati, Asmadi. 2014. Efektivitas Penambahan Serbuk Biji Asam Jawa (Tamarindus Indica) Dalam Menurunkan TSS Pada
Limbah Cair Tahu Di Kecamatan Pontianak Utara Jurnal Penelitian. Pontianak : Jurusan Kesehatan Lingkungan.

Margono, 2010. Penyediaan Air Bersih Buku Ajar Jilid 1. Surabaya : Jurusan Kesehatan Lingkungan Surabaya.

Notoadmodjo, Soekidjo. 2010. Metodologi Penelitian Kesehatan. Jakarta: Rineka Cipta.

Peraturan Gubernur Jawa Timur No. 72 Tahun 2013 Tentang Baku Mutu Air Limbah Bagi Industri Dan/Atau Kegiatan Usaha Lainnya.

Pemerintah Republik Indonesia Nomor 82 tahun 2001 Tentang Pengelolaan Kualitas Air dan Pengendalian Pencemaran Air Presiden Republik Indonesia.

Purwanto, Didik Sugeng. 2010. Pengelolaan limbah cair. Surabaya : Prodi Kesehatan Lingkungan Poltekkes Kemenkes Surabaya.

Sugiharto. 2008. Dasar-Dasar Pengolahan Air Limbah. Jakarta: Universitas Indonesia Press

Sutrisno, T., ( 2006 ), Teknologi Penyediaan Air Bersih, Cetakan Keenam. Jakarta : Rhineka Cipta

Bramantoro, T. Purnomo, W. 2002. 36 langkah praktis sukses menulis karya tulis. Surabaya: PT Revka Petra Media 